UDC $658.62+316.775 .4$

DOI: https://doi.org/10.32782/2224-6282/170-10

\begin{abstract}
Fayvishenko Diana
Doctor of Economic Sciences, Professor at the Department of Journalism and Advertising, Kyiv National University of Trade and Economics ORCID: https://orcid.org/0000-0001-7880-9801
\end{abstract}

Romanchenko Tetiana

Lecturer at the Department of Marketing, Kyiv National University of Trade and Economics ORCID: https://orcid.org/0000-0002-2679-3454

Karmazinova Viktoriia $\mathrm{PhD}$ in Economics,

Kyiv National University of Trade and Economics ORCID: https://orcid.org/0000-0002-8554-1900

Файвішенко Д. С. доктор економічних наук, професор кафедри журналістики та реклами, Київський національний торговельно-економічний університет

Романченко Т. В. викладач кафедри маркетингу, Київський національний торговельно-економічний університет

Кармазинова В. Д. кандидат економічних наук, старший викладач кафедри маркетингу, Київський національний торговельно-економічний університет

\title{
«CUSTOMER JOURNEY» AS A COMPONENT OF STRATEGIC MARKETING
}

The main factors influencing the formation of the main component of strategic marketing of the full cycle "customer journey" in terms of omnichannel strategy of retail networks were analyzed. The main aspects of obtaining customer experience and changes were discovered by identifying customers points of contact with the retail network on the possibility of appropriate changes in the marketing strategy of retail networks and their further adaptation to customer needs. Approaches to the study of customer experience and the application of the results of analysis in the communication strategy of trade enterprises in close connection with marketing channels were systematized. The "customer journey" schemes are constructed, which reflects the possible direction of movement from occurence of the need to the purchase using digital marketing channels. The results of estimating frequency of respondents' use of different variants of the "customer journey" with the confirmation of the hypothesis regarding the choice of optical strategy were presented.

Keywords: full-cycle marketing, omnichannel, optichannel, customer journey, strategic marketing, development strategy.

JEL Classification: M31

\section{ШЛЯХ СПОЖИВАЧА» ЯК КОМПОНЕНТ СТРАТЕГІЧНОГО МАРКЕТИНГУ}

Висока конкурентність, диджиталізація процесів покупки у галузі роздрібної торгівлі, вплив зовнішніх та внутрішніх чинників на діяльність підприємства вимагає пошук нових шляхів вивчення спожсвача та аналіз поведінки. Роздрібні мережі направлені на формування стратегічних напрямів щзодо зміни та адаптаціїдо цзих викликів і відповідно створення кращцого споживчого досвіду. Персоналізований підхід до формування маркетингової збутової стратегії, а також виокремлення перспектив ї̈ удосконалення грунтуються на використанні методологічних підходів щодо проиесу сегментації споживачів із подальшим прогнозованим впливом на иі сегменти. У рамках даного дослідження висунуто гіпотезу, що споживач використовує обмежену кількість маркетингових каналів одного бренду, надано пропозииії щьодо обрання оптиканальної стратегії у найбільш запропонованих релевантних пропозииіях. Проаналізовано основні чинники впливу на формування основної компоненти стратегічного маркетингу повного ичиклу «шлях споживача» у розрізі омніканальної стратегї торговельних мереж. Визначено основні аспекти отримання споживчого досвіду на основі виявлення точок дотику клієнтів з торговельною мережею через трансформацію маркетингової збутової стратегії торговельних мереж та подальшої їі адаптаціїдо потреб споживача. Систематизовано підходи до вивчення споживчого досвіду та застосування результатів аналізу у комунікаційній стратегії підприємств торгівлі у тісному зв'язку з маркетинговими каналами. Побудовано схеми «шлях споживача», які демонструють можливий напрям руху від появи потреби до здійснення купівлі при використанні иифрових маркетингових каналів. Приведено результати оиінювання частотності використання респондентами різних варіантів «шляху споживача» 3 підтвердженням висунутої гіпотези щьоо обрання оптиканальної стратегії. Перспективами подальшого дослідження є розробка методичного інструментарію щодо вибору та реалізації стратегій позиціонування і оцінювання ефективності обраних стратегій, прогнозування наслідків їх впровадження у загальну маркетингову стратегію торговельної мережі.

Ключові слова: маркетинг повного циикла, омніканальність, оптиканальність, илях споживача, стратегічний маркетинг, стратегія розвитку. 
Introduction. High competitiveness, digitalization of purchasing processes in retail, changes in the value orientations of society, the impact of external and internal factors on the enterprise require the search for new ways to study the customer and analyze their behavioral change. Retail networks are aimed at forming strategic directions for change and adaptation to these challenges and to create a better customer experience. The effectiveness of the trade enterprise is determined by the exponential dynamics of the information environment, which is not always taken into account by retail networks as we can see in practice. A personalized approach to the formation of marketing sales strategy, as well as determining the prospects for its improvement are based on the use of methodological approaches to the process of customer segmentation with subsequent projected impact on these segments.

The number of marketing channels available to customers is already significant and will continue to grow. This research hypothesizes that the customer doesn't use all marketing channels of one brand.

Analysis of recent research and publications. The study of customer experience is devoted to the works of S. Haeckel and L. Carbone [1], Bernd Schmitt [2], and J. Seligman [3]. Among national researchers of customer experience management are the works of N. Savytska and O. Zhegus [4], O. Zozulyov [5], but more researches are conducted by consulting companies and advertising agencies, which publish relevant materials on their official websites and present materials at conferences, webinars and business forums. The issues of forming a sales strategy of a trade enterprise and the strength of influence on the "customer journey" remain insufficiently studied.

The aim of our research. This research is focused on customer experience of choosing products on the example of the perfume and cosmetics market, aimed to find out what motivates and persuades customers to buy these products, which "path" the customer takes when choosing goods. Identify the main aspects of customer experience and change by identifying customers points of contact with the retail network on the possibility of appropriate changes in the marketing strategy of retail networks and their further adaptation to customer needs. To identify the main aspects of obtaining customer experience and changes by identifying points of contact between customers and the retail network on the possibility of appropriate changes in the marketing strategy of retail networks and their further adaptation to customer needs.

Materials and methods. A personalized approach to the formation of marketing sales strategy, as well as determining the prospects for its improvement are based on the use of methodological approaches to the process of customers segmentation with subsequent projected impact on these segments. Questionnaires and empirical research, such as observation and comparison, have been used to study the process of buying goods and to distinguish between different target audiences, based on a comprehensive study of the relationship between elements of the customer journey. At the empirical and theoretical levels, methods of analysis and synthesis were used to determine the peculiarities of the use of the customer journey, analysis of the activities of the researched company, etc. The simulation allowed creating a map of the customer journey for the representatives of the target audiences.
Expert evaluation methods and the Delphi method were used to create an adequate model of the developed object of study.

Results. Analysis of the development of information technology and e-commerce in Ukraine suggests that modern information technology and digital tools are fundamentally changing traditional tools of promotion and sales, which directly affects the formation of marketing sales strategy of the retail network. The regularity of the development of digitalized society is to provide the technological basis for the individualization of marketing channels and the formation of customer needs with the use of interactive information technology and personalization of customer demand. According to the research results of Ukrainian customers motivations, it was found that the rational-emotional motivation to purchase goods prevails [6]. In the case of repurchasing a product of a certain product group, it is easier for the customer to make a choice based on previous positive experience, which results in the formation of commitment to the products of a particular brand or retail network.

According to the results of the "The Future of Retail 2030", published by CBRE [7], there is a trend of changes in retail networks. In particular, it is noted that traditional stores focus on the impressions received by customers, on the rethinking of customer shopping experience have a strong impact on new brands and new rental facilities.

Customer interaction, which is based on a multilateral communication flow, arises in the process of moving goods or services, transforms the concept of "sales channel", "distribution channel", "movement channel", "trade channel" into the "marketing channel" and therefore customer becomes a defining element of promotion.

In order to establish an adaptive way of buying, the purpose of which is to complete the buying process at the heart of changing the marketing channel is referral to omnichannel. With omnichannel, all marketing channels are integrated into a single customer-focused system with a history of interaction. Retailers compete to be represented in all channels as close as possible to the customer, without regard to relevance and differentiation. But an undifferentiated approach, along with exceptional customer service and competitive pricing, does not expand the customer database. Most retail purchases in almost all categories start online, but offline sales are much larger than e-sales (except for the period of strict quarantine restrictions in 2020) [8].

To increase the number of customers of a retail network, the use of different marketing channels to increase the size of regular customers database is becoming relevant. The choice of marketing channel by the customer depends on the quantity of goods, assortment and pricing policy, provision of additional services, plan to move the flow of customers within the trade plane, availability of trade equipment, its size, depends on the assortment of the store, atmosphere of the store showcases, convenience of arrival to shop. The success of the marketing strategy of the retail network largely depends on the validity of a set of short-term measures aimed at responding quickly to the market relevant demand. These are activities that directly stimulate the purchasing activity of customers, the work of distributors and sales employees. In the process of substantiation of a set of means of stimulating sales for customers should rely on that their impact is 
short-lived and they are not suitable for the formation of a stable commitment to the brand of the retail network. Studying foreign practice of sales strategies revealed the use of the concept of $\mathrm{O} 2 \mathrm{O}$ (online to offline): $\mathrm{O} 2 \mathrm{O}$ commerce, $\mathrm{O} 2 \mathrm{O}$ analytics. The proposed approach is covered in numerous publications, mainly by Chinese scientists: X. Zhu, B. Song, Y. Ni, Y. Ren, R. Li (2016). It is about bridging the gap between the large number of potential buyers who preview the product on the site of the retail network and the number of potential buyers who go to the store to complete the purchase, so the proposed sales strategy $\mathrm{O} 2 \mathrm{O}$ is a business model in which the Internet and personal communication technologies are used to attract the customer to the traditional journey of buying goods [9].

The experience of the customer visiting the place of purchase not only determines the buying behavior at a given time, but also affects the formation of its corresponding image to the customer. Therefore, the most important thing is to correctly identify the points of interaction. At the same time, we must to understand the mean for the customer depending on the place and circumstances, according to their immediate needs, or when, how and where the process of buying and consuming goods or services.

According to the author's research conducted by the method of questionnaires with a sample of 467 people (age 18-65 y.o.) in the urban population of Kyiv region with $95 \%$ confidence [10], in recent years there has been a change in customer focus and key factors influencing purchasing decisions. Ranking of influencing factors - from the most influential to the least important are presented in table 1 .

Factors influencing the purchase of Ukrainians

\begin{tabular}{|l|c|c|c|c|}
\hline \multirow{2}{*}{} & \multicolumn{2}{|c|}{ Traditional store } & \multicolumn{2}{c|}{ Online store } \\
\cline { 2 - 5 } & $\mathbf{2 0 1 4}$ & $\mathbf{2 0 2 0}$ & $\mathbf{2 0 1 4}$ & $\mathbf{2 0 2 0}$ \\
\hline Low price & $54 \%$ & $49 \%$ & $22 \%$ & $13 \%$ \\
\hline $\begin{array}{l}\text { Convenient location / } \\
\text { fast delivery }\end{array}$ & $47 \%$ & $50 \%$ & $9 \%$ & $26 \%$ \\
\hline Wide range & $44 \%$ & $30 \%$ & $10 \%$ & $8 \%$ \\
\hline Payment by card & $20 \%$ & $25 \%$ & $5 \%$ & $8 \%$ \\
\hline Quality of goods & $19 \%$ & $18 \%$ & $18 \%$ & $17 \%$ \\
\hline
\end{tabular}

Source: Kantar TNS (2014) and author's study (2020) [10]

According to the data from 2020, the main factors influencing the purchase are the speed of delivery $(74 \%$ of respondents also indicate free delivery), current information on the availability of goods for the online store $(53 \%)$ and the ability to test products for stores offline (21\%).

The "Customer journey" scheme covers a wide range of different methods and services aimed at combining markets online and offline, providing information, services, recording discounts in the personal accounts of Internet users and their further application in traditional stores. During the COVID-19 pandemic in China, O2O service platforms developed rapidly, facilitating the purchase of food and delivery of ready meals. Unlike the traditional e-commerce model, in which waiting for an order to be delivered can take days or weeks, customers on $\mathrm{O} 2 \mathrm{O}$ platforms receive them within an hour.

Traditional businesses (hotels, restaurants), which previously refrained from providing online services, have begun cooperation with $\mathrm{O} 2 \mathrm{O}$ platforms.

It is important to emphasize that the services and basic methods of $\mathrm{O} 2 \mathrm{O}$ "online offline" apply to the purchase of goods and services in such fields:

- medical consultations;

- creation of self-pickup points for online orders on the basis of retail stores or warehouses;

- opportunities to return the goods in a traditional store;

- opportunities to place an order online in the store;

- special offers: discounts, online coupons, QR-codes, participation in online games;

- VR - tools.

According to the proposed model, the analysis of existing offline and online marketing channels, identification of points of contact with the customer, current customer preferences, formation of "customer journey", allocation of unprofitable resources and redirection to priority channels with further optimization in accordance with the selected "customer journey".

The customer's choice can be not only one, but several marketing channels (mix), which will affect the chosen marketing sales strategy.

Research and analysis of the world experience of trade enterprises, which are actively implementing it in their activities, the formation of a single high standard of customer service, regardless of the points of involvement in the purchasing process, is becoming relevant.

Customer journey, the strategic goals of the retail network and the existing marketing channels are shown in Fig. 1.

During the research, marketing channels were identified, and priority was given to each studied retail network of perfumes and cosmetics.

Thus, the results of the assessment of the priority of marketing channels of retail networks on the basis of comparison (median by the Delphi method) of expert assessment (E) of the weight of the marketing channel and customer opinion (C) are given in table 2 .

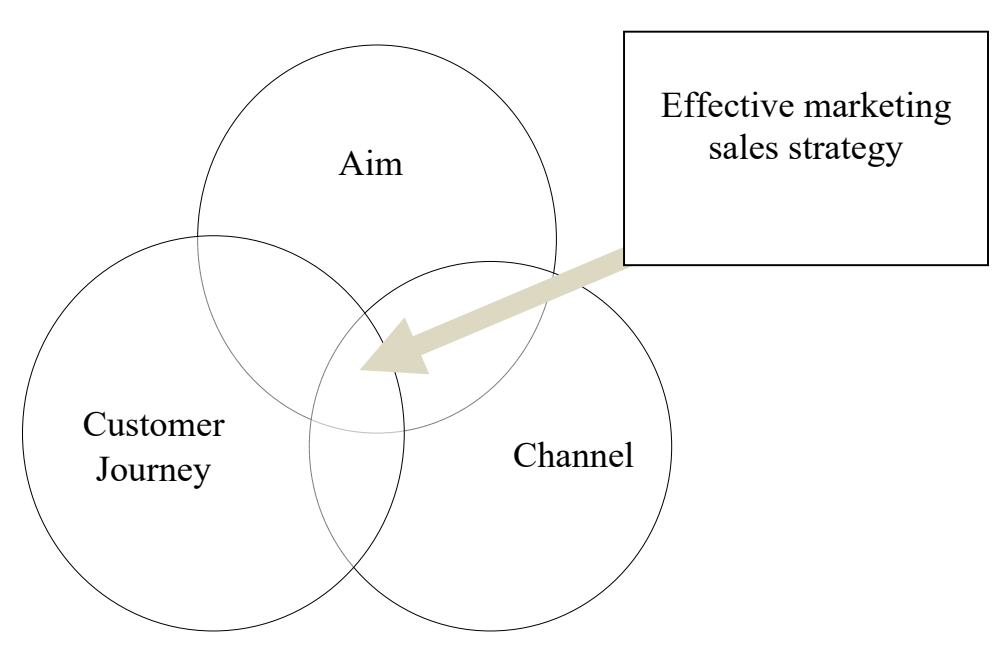

Fig. 1. Components of an effective marketing and sales strategy Source: [11] 
Table 2

Estimation of priority of marketing channels of retail networks

\begin{tabular}{|c|c|c|c|c|c|c|c|c|c|c|c|c|c|c|}
\hline \multirow{2}{*}{$\begin{array}{l}\text { Chain } \\
\text { of stores }\end{array}$} & \multicolumn{2}{|c|}{ Store } & \multicolumn{2}{|c|}{ Internet-shop } & \multicolumn{2}{|c|}{ Application } & \multicolumn{2}{|c|}{$\begin{array}{c}\text { Social } \\
\text { networks }\end{array}$} & \multicolumn{2}{|c|}{ E-mail } & \multicolumn{2}{|c|}{ Messengers } & \multicolumn{2}{|c|}{ Prospectus } \\
\hline & $\mathbf{E}$ & $\mathrm{C}$ & $\mathbf{E}$ & $\mathbf{C}$ & $\mathbf{E}$ & $\mathbf{C}$ & $\mathbf{E}$ & $\mathrm{C}$ & $\mathbf{E}$ & $\mathrm{C}$ & $\mathbf{E}$ & $\mathrm{C}$ & $\mathbf{E}$ & $\mathbf{C}$ \\
\hline Eva & 8 & 9 & 7 & 6 & 3 & 2 & 6 & 5 & 7 & 5 & 8 & 7 & 5 & 4 \\
\hline Prostor & 7,5 & 8 & 6 & 6 & - & - & 7 & 6 & 8 & 5 & 8 & 6 & 4 & 3 \\
\hline Watsons & 8 & 8 & 8 & 5 & 4 & 3 & 7 & 6 & 8 & 8 & 0 & 8 & 4 & 4 \\
\hline Kosmo & 7 & 6 & 6 & 4 & - & - & 3 & 3 & 3 & 4 & 4 & 3 & 3 & 3 \\
\hline
\end{tabular}

Source: according to the author's research

As we can see from the above data, experts and customers are united in prioritizing the channel of traditional stores in the market of perfumes and cosmetics. As for other channels, the opinions of experts and customers differ. It is believed that a marketing channel such as e-mail is optimal in terms of investment and, accordingly, the conversion to purchase by this channel is higher than, for example, in social networks.

According to Campaign Monitor, the ROI of the e-mail channel, depending on the industry is $3800 \%-4000 \%$ [12]. However, customers point out such shortcomings as the inability to choose the frequency of receiving e-mails from retail networks, the irrelevance of offers, impersonal mailings (only in the Watsons retail network each letter indicates the number of bonuses on the personal account).

Therefore, for each network the ranking of marketing channels is carried out and the comparative characteristics of marketing channels of retail networks by priority are presented in table 2 .

Comparison of marketing retail networks channels by priority

\begin{tabular}{|l|c|c|c|}
\hline & Experts & Customers & Total \\
\hline Store & $7.625(1)$ & $7.75(1)$ & $7.69(1)$ \\
\hline Internet-shop & $6.75(4)$ & $5.25(4)$ & $6.0(4)$ \\
\hline Application & $3.5(7)$ & $2.5(7)$ & $3.0(7)$ \\
\hline Social networks & $5.75(5)$ & $5.0(6)$ & $5.38(5)$ \\
\hline E-mail & $6.5(3)$ & $5.5(3)$ & $6.0(3)$ \\
\hline Messengers & $7.25(2)$ & $6.0(2)$ & $6.63(2)$ \\
\hline Prospectus & $4(6)$ & $3.5(6)$ & $3.75(6)$ \\
\hline
\end{tabular}

Source: according to the author's research

According to the collected data, for retail networks of perfumes and cosmetics in Ukraine, the second most important is the messenger channel, and then e-mail. In the absence of opportunities to evaluate online stores, connections and such a channel as "prospectus", so the distribution of prospectus is carried out in mainly through a network of stores, which means that loyal customer communicate with the brand in messengers, carefully reading emails, migrating to the channel Online store, search for the necessary goods and make a purchase.

However, the number of marketing channels, even within one retail network, cannot define one "customer journey" as more typical. Here's an example of a digital customer journey built with the Google Ads Associated Conversion Tool.

There was a low coefficient that the digital customer journey does not coincide with reality [13].
As can be seen from the above diagram, from the moment of receiving the offer to buy goods to making a purchase, the customer visits sites with reviews, social networks, watches a number of videos, visits sites of various retail networks, searches for more attractive price and finally makes a purchase from the site. The "Customer journey" scheme may end in a traditional store, but with the digitalization of society, wherever it begins and ends, the number of steps increases significantly, even if the customer prefers a particular marketing channel. The process of online purchase of perfumes and cosmetics (PC) is presented schematically, as shown in Fig. 3.

According to the author's research, most retail purchases of perfumes and cosmetics begin on the Internet, but sales thru brick and mortar stores are much higher.

Customers of perfumes and cosmetics were distributed according to the algorithm of purchase as follows:

1. Those who make purchases exclusively in traditional stores ( $52 \%$ of respondents).

It is difficult to encourage such customers to repeat purchases, but it is possible if they participate in the loyalty program. The most important thing is the fact of making a purchase, so it is mandatory at the checkout to take contact information, at least a mobile phone to provide information about current promotions and discounts. Trying to switch the customer to other channels of the retail network, for example, to the online store means shifting the number of purchases in favor of online channels through active interaction: the assessment of a store visits to calculate the NPS. Depending on the composition of purchases in the check, reminders that cosmetics are running out and an individual offer are effective. Or offer to leave feedback about the store on Google Maps or social networks. Under the condition of a positive customer experience, buyers agree to such interaction without reward. With negative experience, the retail network has the opportunity to work out comments to change the customer attitude.

2 . Those who make purchases exclusively online (23\% of respondents).

Provided that the web analytics is set up correctly, such customers are tracked online using remarketing and other digital marketing tools. Depending on the point of contact of the customer journey, possible interaction algorithms differ in stages, but the same principles of interaction remain: request to leave feedback on the purchase process, encouragement to leave feedback on purchased goods and reminders to buy again in the communication. Retail networks that use monitoring of mentions on the Internet communicate directly with customers, thank them for the positive feedback and work out the negative ones. 


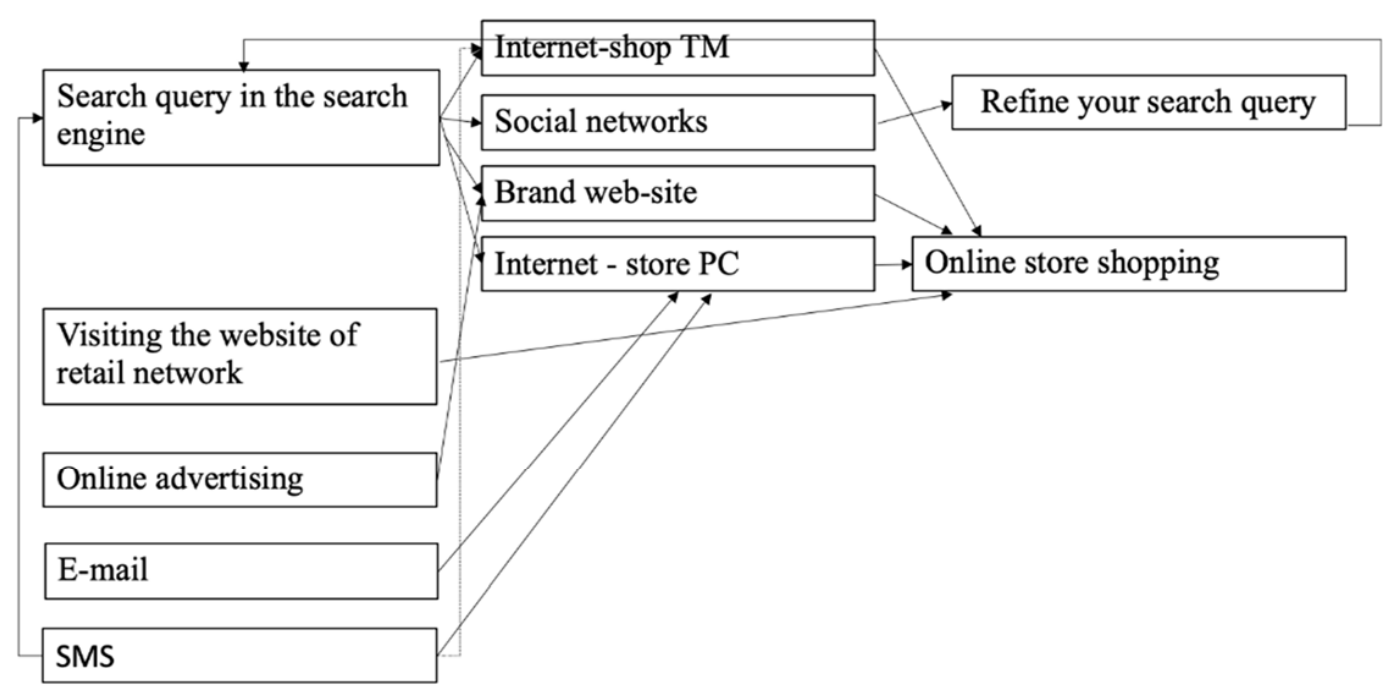

Fig. 2 Generalization of the process of online purchase of PC

Source: according to the author's research

Table 4

Marketing channels of $\mathrm{PC}$ retail networks in Ukraine

\begin{tabular}{|c|c|c|c|}
\hline TM & Main Marketing Channel & Additional Marketing Channel & Other marketing channels \\
\hline Yves Rocher & E-mail & Prospectus & SMS, messengers, social networks \\
\hline Eva & Social networks & E-mail & Messengers \\
\hline Watsons & E-mail & Messengers & Social networks \\
\hline Prostor & Messengers & E-mail & Social networks, SMS \\
\hline Kosmo & Messengers & E-mail & Social networks, SMS \\
\hline
\end{tabular}

Source: according to the author's research

3. Those who are not limited to one channel for shopping ( $25 \%$ of respondents).

The author's research showed that in $82 \%$ of cases, online purchases are made after the customer has made a purchase in a traditional store and was satisfied with the service and quality of goods. Online orders consisted of previously purchased goods, repeat purchases were made regularly, ie subject to customer loyalty to the retail network, such buyers decided to save time visiting the store. However, if in the case of a negative experience of buying in a physical store, customers agree to return to such a store (due to the convenience of location), in case of online ordering, and negative experience with purchase delivery, customers in $74 \%$ do not agree to order again. Their decision can be changed by free delivery, but only $24 \%$ of respondents agreed to buy again under such conditions. Given that the delivery of Internet orders can be performed by contractors who are not employees of the retail network, the negative experience of delivery of such orders is a reserve for increasing the number of purchases among multi-channel customers.

Another decisive factor mentioned by the respondents is the incorrect information about the availability of goods at the time of purchase and the waiting time for the order for more than 3 days. At the same time, the retail network can unilaterally cancel an already paid order, refunds are made in at least three days, for $16 \%$ of respondents such actions do not meet expectations and therefore cause negativity, which is then observed in reviews on retail sites and customer pages in social networks. Marketing channels of PC retail networks in Ukraine presented in table 4.

Thus, the "customer journey" scheme is important for the optimization of sales and service processes, considering the focus on transactional customer relationship in terms of omnichannel strategy of retail networks. It is important to consider all stages of customer interaction with the retail network "life journey", which will build a closer operational relationship with the brand, eliminate the factor of frustration and negative attitude towards the product.

Conclusions. Today, retail networks are actively studying the "customer journey", restructuring trade proposals, developing, and managing controlled points of contact, responding to uncontrolled points of contact, offering additional services to influencers.

According to the results of the reserch, "customer journey" scheme are constructed, which reflects the possible direction of movement from requirement of need to make a purchase using both digital and traditional marketing channels.

Evaluation of the frequency of respondents' use of different options of the "customer journey" confirmed the hypothesis of each customer's choice from 1 to 3 most convenient marketing channels and confirmed the hypothesis of choosing an omnichannel strategy using interactive interaction with sellers or retail networks.

The sale of goods is an act of recognition of the marketing efforts of the seller in the field of formation and satisfaction of customer needs, which in turn ensures the competitiveness and growth of financial results of the retail 
network. There is a shift in emphasis in sales management from short-term profit to strategic development and sales management, the formation of sustainable long-term relationships with target customers, the formation and maintenance of the most useful, innovative customer experience.

Based on the application of demographic indicators and psychography for a multi-channel strategy, it is important to analyze the choice of channels by customers and their further adaptation to needs. Instead, opticality as a universal strategy uses aggregate data to adapt the level of interaction with the customer, a higher level of personalization.

Prospects for further research are the development of methodological tools for selecting and implementing strategies for positioning and evaluating the effectiveness of selected strategies, forecasting the consequences of their implementation in relation to the overall marketing strategy of the retail network.

\section{References:}

1. Carbone L.P., Haeckel S.H. (1994) Engineering Customer Experiences. Marketing Management Journal, vol. 3, pp. 1-14.

2. Schmit B. (2015) Managing the brand experience. The Future of Branding, SAGE Publications India, pp. 177-198.

3. Seligman J. (2012) Customer experience in modern marketing. Lulu Press. 170 p.

4. Savytska N., Zhehus O.V., Afanasieva O.P. (2016) Trade marketing modern tools and technologies. Managing economic growth: marketing, management, and innovations. 1st ed. / Prague Institute for Qualification Enhancement. Prague, pp. 545-554.

5. Garachkovska O., Sytnyk O., Fayvishenko D., Taranskiy I., Afanasieva O., Prosianyk O. (2021) Strategic Management of Brand Positioning in the Market Advances in Science. Technology and Engineering Systems Journal, vol. 6, no. 1, pp. 947-953. Available at: www.astesj.com.

6. Bogomaz N.V., Zozulov O.V. (2002) The method of integrated assessment of customer attitudes to the brand. Marketing in Ukraine, no. 6, pp. 30-33.

7. The future of retail 2030 is the technology of accelerating change, or how we will make purchases in 2030. CBRE Ukraine. Available at: https://cbre-expandia.com/maybutnye-riteylu-2030-tehnologiya-priskorennya-zmin-abo-yak-mi-budemo-zidysnyuvatipokupki-v-2030.

8. Customer sentiment of Ukrainians in 2020. Delloite study. Available at: https://www2.deloitte.com/en/en/pages/press-room/ press-release/2021/2020-customer-behavior-in-ukraine.html

9. Xiaoming Zhu, Bingying Song, Yingzi Ni, Yifan Ren, Rui Li (2016) The O2O Model - From Online/Offline to the O2O Model. Business Trends in the Digital Era. Evolution of Theories and Applications, pp. 191-212.

10. On-line shopping in Ukrainian: what more often Ukrainians buy on-line and what stops them from online shopping. Available at: https://tns-ua.com/news/on-line-shopping-po-ukrainski-chto-chashhe-ukraintsyi-pokupayut-on-line-i-chto-ih-ostanavlivaet-otinternet-pokupok

11. Romanchenko T.V. (2020) Marketing sales strategy of the retail network. Dissertation for the degree of Doctor of Philosophy. Kyiv: KNTEU.

12. McKorkle S. Why email marketing is still in style and thriving. Available at: https://venturebeat.com/2015/03/05/why-emailmarketing-is-still-in-style-and-thriving.

13. Maechler N., Neher K, Park R. From touchpoints to journeys: Seeing the world as customers do. Available at: https://www.mckinsey.com/business-functions/marketing-and-sales/our-insights/from-touchpoints-to-journeys-seeing-the-world-ascustomers-do . 